\title{
Manajemen Pengembangan Karakter Muslim Moderat Pada Siswa Madrasah Aliyah
}

\author{
Musta'in Ahmad $^{1 *}$, Giyoto $^{2}$, Rochmat Budi Santoso ${ }^{3)}$ \\ ${ }^{1,2,3}$ Institut Agama Islam Negeri (IAIN) Surakarta \\ *Email: musta'inahmad@gmail.com
}

The study of the concept of religious moderation in Islam or moderate Islam that has attracted the attention of Muslim scholars in fields of study such as socio-politics, Islamic education, language, and socio-religion. These terms are the meanings of various meanings used to label Muslims such as Modernist, Reformed and progressive Islam. This study aims to look at the management of moderate Muslim character among Islamic school students. The implementation of this research was conducted at Madrasah Aliyah Negeri 2 Surakarta. The methodology in this study uses a qualitative approach. Techniques of studying data in this study are observation, interviews and documentation. The method used to check the validity of the data is the triangulation method. Data analysis in this study used qualitative analysis. The results showed that the management of moderate Muslim character development in madrasah aliyah students at Madrasah Aliyah Negeri 2 Surakarta was carried out with several things that could make the character of the students able to understand and appreciate every difference, namely 1) Implementation of the curriculum in Madrasah Aliyah Negeri 2 Surakarta Islam. moderate is given in several subjects, especially subjects related to religious morals and morals such as PAI, Akidah Akhlak and several other subjects. 2) Madrasah Aliyah Negeri 2 Surakarta, there are several forms of integration related to moderate or moderate understanding of Islam in religion which is always applied in the madrasa environment, including through the learning process delivered by each teacher in the classroom, then through the process of understanding that has been realized. by Madrasah Aliyah Negeri 2 Surakarta through the culture in madrasah and the understanding that has been applied through various extracurricular activities.

Keywords: management, character development, moderate Muslims, madrasah aliyah

\begin{abstract}
Abstrak
Pengkajian tentang konsep moderasi beragama dalam Islam atau Islam moderat menarik perhatian bagi cendekiawan muslim dalam bidang kajian seperti sosio-politik, pendidikan Islam, bahasa, dan sosial keagamaan. Pengistilahan tersebut merupakan arti dari berbagai makna digunakan membuat label umat Islam seperti Islam Modernis, Reformis dan progresif. Penelitian ini bertujuan untuk mengetahui manajemen pengembangan karakter muslim moderat pada siswa madrasah aliyah. Pelaksanaan penelitian ini dilakukan di Madrasah Aliyah Negeri 2 Surakarta. Metodologi dalam penelitian ini menggunakan pendekatan kualitatif. Teknik pengumpulan data pada penelitian ini yaitu dengan observasi, wawancara dan dokumentasi. Metode yang digunakan untuk memeriksa keabsahan data adalah dengan triangulasi method. Analisis data dalam penelitian ini menggunakan analisa kualitatif. Hasil penelitian menunjukkan bahwa manajemen pengembangan karakter muslim moderat pada siswa madrasah aliyah yang ada di Madrasah Aliyah Negeri 2 Surakarta dilakukan dengan beberapa hal yang dapat membuat karakter para siswa mampu memahami dan menghargai setiap perbedaan, yaitu 1) Penerapan kurikulum di Madrasah Aliyah Negeri 2 Surakarta terkait Islam moderat diberikan dibeberapa mata pelajaran, kususnya mata pelajaran yang berkaitan dengan akidah dan akhlak agama ini seperti mata pelajaran PAI, Akidah Akhlak dan beberapa mata pelajaran lain. 2) Madrasah Aliyah Negeri 2 Surakarta terdapat beberapa bentuk integrasi terkait dengan pemahaman Islam moderat atau moderat dalam beragama yang selalu senantiasa di terapkan di lingkungan madrasah, antara lain melalui proses pembelajaran yang disampaikan setiap guru di dalam kelas, selanjutnya melalui proses pemahaman yang telah diwujudkan oleh Madrasah Aliyah Negeri 2 Surakarta melalui budaya di madrasah serta pemahaman yang telah diterapkan melalui berbagai kegiatan ekstrakurikuler.
\end{abstract}

Kata kunci: manajemen, pengembangan karakter, muslim moderat, madrasah aliyah 
Saran sitasi: Ahmad, M., Giyoto., \& Santoso, R. B. (2021). Manajemen Pengembangan Karakter Muslim Moderat Pada Siswa Madrasah Aliyah. Jurnal Ilmiah Ekonomi Islam, 7(01), 475-483. doi:http://dx.doi.org/10.29040/jiei.v7i1.2290

\section{DOI: http://dx.doi.org/10.29040/jiei.v7i1.2290}

\section{PENDAHULUAN}

Moderasi beragama dalam Islam dikenal dengan wasattiyah merupakan aspek ajaran yang mengandung nilai moral yang relevan untk membangun perilaku individual, baik integritas dan citra diri masyarakat dan bangsa. Dalam pandangan Alquran moderasi memiliki konsekuensi luas di hampir semua bidang yang menjadi perhatian Islam, seperti yang terefleksi pada identitas diri dan pandangan dunia komunitas Muslim (Kamali, 2015). Secara umum ada alasan penting untuk mengkorelasikan antara pendidikan Islam dengan moderasi, yaitu penguatan pemahaman tentang moderasi dan memahami keagamaan dalam pendidikan Islam. Pengembangan karakter untuk membentuk moderasi beragama dalam dunia lembaga pendidikan sangat dibutuhkan sekali sebagai upaya dan usaha untuk penguatan dan pemahaman tentang moderasi beragama itu sendiri agar dapat dipahami secara utuh. Menurut Soemantri (2011) yang dikutip oleh Darmawan menyatakan bahwa lembaga pendidikan harus sebagai menara air bagi masyarakatnya. Lembaga pendidikan mampu memancarkan hikmah dan kebahagiaan tersendiri bagi masyarakat, yang berakhir pada pusat peradaban terhadap pembangunan. Lembaga pendidikan sebagai salah satu aktor atau pemeran untuk melakukan perubahan, terutama pada perubahan sosial dalam pembangunan yang berkelanjutan.

Tilaar (2004) dalam pendapatnya menyatakan bahwasanya lembaga pendidikan sebagai pengganti kata hati masyarakat karena tingkat pengetahuannya belum memiliki kemampuan untuk berpikir secara mandiri. Tanggung jawab secara moral lembaga pendidikan dalam situai seperti itu merupakan suatu keharusan dan secara umum bertanggung jawab terhadap tanggung jawab moral. Pembelajar dalam dunia pendidikan atau lembaga pendidikan merupakan pelaku penting dalam menanamkan nilainilai moderasi bergama termasuk nilai-nilai moderasi Islam. Lembaga pendidikan bagian penting untuk menjadi laboratorium dalam moderasi beragama. Seperti yang telah dipahami bangsa Indonesia adalah bangsa yang mempunyai berbagai macam keunikan dan keragaman, termasuk di dalamnya yaitu berupa ragam suku serta ragam agama. Indonesia dalam hal tersebut mempunyai keunikan, akan tetapi di tengah berbagai keunikan itu pulalah membuat bangsa ini penuh dengan berbagai tantangan pula. Sekolah sebagai institusi pendidikan dapat menumbuhkan pola pikir moderasi beragama atau moderasi Islam dengan kondisi bahwa pandangan eksklusif dan tindakan ekstremis berupa tindakan kekerasan dalam baju agama akan merusak berbagai sendi kehidupan kebangsaan yang sangat majemuk.

Penerapan moderasi beragama saat ini menjadi perhatian khusus bagi pemerintah terutama dari Kementerian Agama Republik Indonesia secara khusus melalui Direktorat Jenderal Pendidikan Islam. Hal ini perlu disikapi dengan memberikan kontribusi dalam pengembangan karakter muslim moderat dikalangan siswa madarasah melalui pendekatan manajemen pengembangan karakter khususnya bagi para siswanya. Untuk merealisasikan sikap pengembangan karakter moderasi keislaman perlu dilakukan pengkajian atau penelitian, yaitu manajemen pengembangan karakter moderasi Islam, problematika dan kendala pengembangan karakter dan penyelesaian problematika yang dilakukan oleh lembaga pendidikan.

Pada tahun 2013 pemerintah mengeluarkan kebijakan baru berupa kurikulum 2013, dengan diterbitkannya Peraturan Menteri Agama Republik Indonesia No. 90 tahun 2013 tentang penyelenggaraan madarasah. Didukung dengan peraturan Meneteri Agama Republik Indonesia tentang kurikulum madarasah 2013. Perubahan kebijakan pemerintah memiliki dampak pengembangan karakter pada siswa. Dari pembentukan kurikulum tersebut membentuk jiwa siswa yang menerima kekurangan dan kelebihan dari masing-masing mereka satu sama lainnya, sehingga tercipta suasana saling menghargai perbedaan yang ada.

Madrasah Aliyah Negeri 2 Surakarta merupakan madrasah aliyah yang memiliki banyak keunggulan di bidang akademik maupun non akademik. Di tengah banyaknya keunggulan atau prestasi yang telah diraih tersebut, madrasah aliyah ini juga memberikan mata pelajaran-mata pelajaran yang berkaitan dengan manajemen pengembangan karakter bagi para peserta 
didiknya. Sebagai sekolah negeri yang berbasis keagamaan Islam, Madrasah Aliyah Negeri 2 Surakarta mengajarkan pola pikir dan tindakan kepada para siswanya agar senantiasa menghargai setiap perbedaan yang ada, baik perbedaan ras, suku, serta berbagai perbedaan lainnya termasuk perbedaan agama. Meskipun lingkungan Madrasah Aliyah Negeri 2 Surakarta semua siswanya beragama Islam namun pelajaran manajemen pengembangan karakter semacam itu disampaikan agar nantinya ketika di lingkungan masyarakat mereka mampu menerapkan karakter tersebut terhadap saudara-saudara mereka meskipun memiliki perbedaan dalam keyakinan atau agama sebagai wujud generasi muslim yang moderat.

Berdasarkan latar belakang masalah yang telah dijabarkan di atas, peneliti tertarik melakukan penelitian di Madrasah Aliyah Negeri 2 Surakarta tetang manajemen pengembangan karakter muslim moderat pada siswa madrasah aliyah, yang tentunya manajemen yang ada dilakukan oleh pihak Madrasah Aliyah Negeri 2 Surakarta terhadap para peserta didiknya dalam mensikapi berbagai berbedaanperbedaan serta keragaman yang ada baik saat di lingkungan madrasah maupun saat di lingkungan masyarakat.

\section{KAJIAN TEORI}

\subsection{Konsep Islam Moderat}

Moderat berarti menghindarkan perilaku yang ekstrem atau pengungkapan yang ekstrem dan lebih memilih ke arah jalan tengah dengan mempertimbangkan pandangan pihak lain. Moderat mempunyai arti yang sama dengan moderasi, yakni pengurangan kekerasan atau penghindaran keekstreman (KBBI, 2008). Moderat dalam istilah Arab dikenal dengan kata tawassuth, at-tawazun atau al-wasathiyyah yang berarti jalan tengah di antara dua kutub yang saling berlawanan. Sikap tawassuth berarti sikap yang berkaitan pada prinsip hidup yang menjunjung tinggi perlakuan adil serta lurus di tengah jalan kehidupan bersama.2 Bentuk-bentuk kemoderatan dalam Islam dapat diklasifikasikan dalam berbagai ragam pranata kehidupan beragama antara lain yaitu keseimbangan teologi, keseimbangan ritual keagamaan, keseimbangan moralitas dan budi pekerti serta keseimbangan tasyri' (pembentukan hukum) (Maarif, 2018).

Islam merupakan agama yang mempunyai semangat toleransi yang tinggi. Islam bersifat moderat yakni adil dan mengambil jalan tengah. Menurut Ibnu
'Asyur, para ulama' telah mencapai kata mufakat bahwa sikap moderat yakni tidak ekstrem ke kanan dan tidak juga ekstrem ke kiri merupakan sifat mulia yang dianjurkan oleh Islam. Seperti firman Allah SWT, Dan Kami juga telah menciptakan kalian sebagai umat moderat (Q.S.: Al-Baqarah (2), 143). Matharaf Ibn Abdullah Al-Syahir Al-Taba'i menegaskan bahwa perkara yang paling baik adalah yang paling moderat. Dengan cara itulah umat Islam akan menjadi umat yang mampu memberikan harapan untuk kehidupan yang lebih mengedepankan dialog dan cara-cara damai (Misrawi, 2010). Asyraf Abdul Wahhab menjelaskan bahwa aspek yang penting dalam toleransi adalah menumbuhkan kesabaran dan sikap moderat. Sikap sabar mempunyai makna yang mendalam, yakni sikap yang tidak melakukan tindakan kekerasan terhadap pihak lain. Sabar mempunyai kerelaan untuk memaklumi eksistensi pihak lain dan seseorang yang sabar tidak akan mengutamakan kekerasan sebagai jalan keluar dalam setiap persoalan. Sikap moderat juga tidak akan mengambil langkah-langkah ekstrem dalam menyelesaikan kesalahan dan perbedaan yang dilakukan pihak lain, hal ini dikarenakan kesalahan dan perbedaan merupakan hal manusiawi. Seseorang yang memiliki sikap moderat, bila sedang melakukan sebuah percakapan, maka tidak dalam rangka menjatuhkan lawan, namun melakukan interaksi pemahaman yang bilamana ditemukan titik temu maka memungkinkan untuk melakukan kerjasama. Tetapi bila terdapat perbedaan, maka dianggap sebagai suatu realitas yang harus dihargai dan dihormati. Sikap moderat dan kesabaran merupakan sikap yang proaktif dalam rangka mengedepankan toleransi (Misrawi, 2010).

Moderat merupakan salah satu ciri khas dari kalangan Ahlussunnah wal Jamaah termasuk dua organisasi Islam besar di Indonesia yakni Nahdlatul Ulama (NU) dan Muhammadiyah. Nahdlatul Ulama (NU) berusaha senantiasa berada di garda depan untuk menyuguhkan paham keagamaan moderat yang mempunyai akar kuat dalam khazanah keislaman Ahlussunnah wal Jamaah dan juga mampu menyerap berbagai ide baru yang membawa kemaslahatan bagi umat. Pemikiran moderat dikedepankan oleh organisasi Islam Nahdlatul Ulama didasarkan atas beberapa alasan. Pertama, sikap moderat merupakan sikap yang paling adil dalam menerjemahkan teks suci untuk kehidupan sehari-hari di satu sisi dan memahami realitas kehidupan kekinian sebagai fakta 
yang mesti diakomodasikan di sisi lain. Pada tahap ini sikap moderat selalu memahami teks tidak secara harfiyah (literal), tetapi sebagai nilai universal, seperti keadilan, kedamaian, kesetaraan dan kemanusiaan. Islam yang sesungguhnya adalah Islam yang humanis dan rahmatal lil'alamin. Kedua, muslim moderat selalu mengutamakan perdamaian dan menolak kekerasan. Hal ini disebabkan ketika membaca AlQur'an, yang pertama ditemukan adalah lafal bismillahirrahmanirrahim (dengan menyebut nama Allah yang Maha Pengasih lagi Maha Penyayang). Hal ini berarti, Islam adalah agama yang penuh dengan kasih sayang dan jauh dari ajaran kekerasan. Ketiga, kalangan moderat akan memahami bahwa umat agama lain sebagai makhluk Tuhan yang harus dilindungi karena keragaman merupakan sunnatullah. Keragaman adalah fakta yang tidak bisa dihindarkan, oleh karenanya tidak ada pilihan kecuali "melindungi" dan menghargai. Seperti dalam sistem politik klasik bahwa non muslim yang berada di bawah kekuasaan muslim sebagai ahldzimmah, yakni warga negara yang wajib dilindungi. Bahkan, di Madinah Rasulullah Muhammad SAW. menyebutkan bahwa nonmuslim sebagai satu umat bersama orang-orang muslim (ummatun wahidah). Keempat, demokrasi dan hak asasi manusia selalu diutamakan oleh kalangan moderat. Islam mendorong manusia agar menjadikan demokrasi manusia sebagai alternatif. Dalam AlQur'an disebutkan agar semua persoalan diselesaikan dengan mekanisme konsensus, yakni musyawarah untuk mencapai mufakat. Konsep ibadah atau penghambaan hanya kepada Allah SWT, bukan kepada manusia, apapun jabatannya, menandakan bahwa manusia dihadapan Allah SWT itu setara dan sederajat. Sehingga Islam juga menjunjung tinggi hak asasi manusia. Allah SWT melarang adanya eksploitasi dan dominasi seseorang terhadap orang lainnya.

Nilai-nilai Islam Moderat dalam hal ini adalah nilai-nilai Islam moderat yang terkandung dalam proses belajar mengajar dan materi pembelajaran yang diintegrasikan pada pendidikan karakter. Integrasi berarti percampuran, perpaduan dan pengombinasian. Integrasi biasanya dilakukan dalam dua hal atau lebih yang mana masing-masing dapat saling mengisi (Wiyani, 2013). Islam merupakan agama yang mempunyai semangat toleransi yang tinggi. Islam bersifat moderat yakni adil dan mengambil jalan tengah. Kata moderat ini bila dihubungkan pada delapan belas nilai pendidikan karakter, maka nilai karakter yang tepat untuk menggambarkan nilai Islam moderat adalah religius, toleransi, peduli sosial, demokratis dan cinta damai. Religius adalah sikap dan perilaku yang patuh dalam menjalankan ajaran agama yang dianutnya, toleran terhadap pelaksanaan ibadah agama lain dan hidup rukun dengan pemeluk agama lain. Toleransi merupakan Sikap dan tindakan yang menghargai perbedaan agama, suku, etnis, pendapat, sikap dan tindakan orang lain yang berbeda dari dirinya. Sedangkan peduli sosial adalah Sikap dan tindakan yang selalu ingin memberi bantuan pada orang lain dan masyarakat yang membutuhkan (Zubaedi, 2012).

\subsection{Konsep Manajemen Pendidikan Islam}

a. Konsep Dasar Manajemen

Istilah manejemen peningkatan mutu berbasis madrasah/sekolah merupakan model manajemen yang memberikan otonomi lebih besar kepada madrasah/sekolah, memberikan keluwesan kepada warga madrasah serta mendorong madrasah/sekolah meningkatkan partisipasi masyarakat dalam meningkatkan mutu pendidikan. Dengan demikian madrasah/sekolah memiliki kewenangan lebih besar dalam mengelola madrasah/sekolah. Menetapkan penyusunan perencanaan program peningkatan mutu, melaksanakan perencanaan program peningkatan mutu, dan melakukan monitoring serta mengevaluasi perencanaan program peningkatan mutu pendidikan. Dalam melaksanakan pengingkatan mutu pendidikan tersebut, tentulah diperlukan perencanaan dan langkah-langkah operasional secara bertahap. Selanjutnya hasil pelaksanaan kegiatan tersebut harus dimonitoring dan evaluasi secara periodik untuk mengetahui pencapaian target dan perkembangan yang terjadi pada kelembagaan pendidikan tersebut. Pada dasarnya manejemen dapat diartikan berdasarkan beberapa pendapat, yaitu:

1) Longnecker \& Pringle, merumuskan manajemen sebagai proses memperoleh dan menggabungkan sumber-sumber manusia, financial, dan fisik untuk mencapai tujuan pokok organisasi menghasilkan produk atau jasa/layanan yang diinginkan oleh sekompok masyarakat.

2) Siagan (1978), menyebutkan manajemen adalah kemampuan dan keterampilan untuk memperoleh suatu hasil dalam rangka pencapaian tujuan melalui kegiatan-kegiatan 
orang lain. Gr. Terry dalam bukunya Principles of Management (1972) menyebutkan bahwa manajemen merupakan suatu proses yang khas yang terdiri dari tindakan-tindakan perencanaan, pengorganisasian, penggerakan, dan pengendalian yang dilakukan untuk menentukan serta mencapai sasaran-sasaran yang telah ditentukan melalui pemanfaatan sumber daya lainnya.

3) Manajemen adalah suatu proses/kegiatan/usaha pencapaian tujuan tertentu melalui kerja sama dengan orang lain, di mana dapat dimanfaatkan dan digunakan sebagai sumber dan sasaransasaran manajemen.

4) Manajemen adalah suatu kerangka kerja yang terdiri atas berbagai bagian/komponen yang secara keseluruhan saling berkaitan dalam organisasi yang sedemikian rupa dalam mencapai tujuan (management as a system) (Simbolon 2017).

Dari uraian beberapa pengertian manajemen di atas dapat disimpulkan bahwa manajemen adalah suatu rangkaian kegiatan terorganisir dengan cara memanfaatkan semaksimal mungkin bagian atau komponen penting yang terdapat dalam suatu organisasi atau lembaga untuk mencapai suatu tujuan yang telah ditetapkan.

Mengenai fungsi-fungsi manajemen ini terdapat banyak sekali pandanganpandangan yang berbada satu sama lain di kalangan para ahli. Namun secara garis besar, fungsi-fungsi manajemen yaitu:

1) Perencanaan (Planning)

Perencanaan merupakan salah satu hal terpenting yang perlu dibuat untuk setiap usaha dalam rangka mencapai suatu tujuan. Karena seringkali pelaksanaan suatu kegiatan akan mengalami kesulitan dalam mencapai tujuan tanpa adanya perencanaan. Perencanaan sendiri adalah penentuan secara matang dan cerdas tentang apa yang akan dikerjakan di masa yang akan datang dalam rangka mencapai tujuan. Ananda \& Amiruddin (2019) mengatakan bahwa perencanaan adalah proses mempersiapkan seperangkat keputusan bagi perbuatan di masa datang. Definisi ini mengisyaratkan bahwa pembuat keputusan merupakan bagian dari perencanaan. Namun, proses perencanaan dapat juga terpikir setelah tujuan dan keputusan diambil.
2) Pengorganisasian (Organizing)

Istilah organisasi mempunyai dia pengertian utama. Pertama, organisasi diartikan sebagai suatu lembaga atau kelompok fungsional, misalnya, sebuah perusahaan, sebuah sekolah, sebuah perkumpulan, dan badan-badan pemerintahan. Kedua, merujuk pada proses pengorganisasian yaitu bagaimana pekerjaan diatur dan dialokasikan di antara para anggota, sehingga tujuan organisasi itu dapat tercapai secara efektif (Fattah, et. al., 2009). Dari pengertian tersebut dapat dipahami bahwa pengorganisasian adalah pengaturan setelah ada rencana. Dalam pendapat lain, pengorganisasian adalah proses penentuan, pengelompokan, dan penyusunan macammacam kegiatan yang diperlukan untuk mencapai tujuan, penempatan orang-orang (staf) pada kegiatan-kegiatan ini, penyediaan faktor-faktor fisik yang cocok bagi lingkungan (keperluan kerja) Dengan demikian, dalam pandangan penulis, bahwa pengorganisasian merupakan fungsi administrasi yang dapat disimpulkan sebagai kegiatan menyusun struktur dan membentuk hubungan-hubungan agar diperoleh kesesuaian dalam usaha pencapaian tujuan bersama.

3) Penggerakan (Actuating)

Penggerakan pada dasarnya merupakan fungsi manajemen yang kompleks dan ruang lingkupnya cukup luas serta berhubungan erat dengan sumber daya manusia. Penggerakan merupakan salah satu fungsi terpenting dalam manajemen. Penggerakan adalah hubungan erat antara aspek-aspek individual yang ditimbulkan dari adanya pengaturan terhadap bawahan untuk dapat dimengerti dan pembagian kerja yang efektif dan efesien untuk mencapai tujuan yang nyata.

4) Pengawasan (Controling)

Menurut Murdick pengawasan merupakan proses dasar yang secara esensial tetap diperlukan bagaimanapun rumit dan luasnya suatu organisasi. Proses dasarnya terdiri dari tiga tahap (a) menetapkan standar pelaksanaan, (b) mengukur pelaksanaan pekerjaan dibandingkan dengan standar, dan (c) menentukan kesenjangan (deviasi) antara pelaksanaan standar dan rencana. 
b. Manajemen Pendidikan Islam

Manajemen berasal dari bahasa latin, yaitu berasal dari kata manus,yang berarti tangan; dan agree yang berarti melakukan. Kata-kata itu digabung menjadi kata kerja managere; yang artinya menangani. Managere diterjemahkan ke dalam bahasa Inggris; dalam bentuk kata kerja to manage, dalam bentuk kata benda management, dan manager untuk orang yang melakukan kegiatan manajemen. Akhirnya, management ditransliterasi ke dalam bahasa Indonesia menjadi manajemen dengan arti pengelolaan (Usman, 2013). Sedangkan pengertian manajemen secara istilah adalah pemanfaatan sumber daya secara efektif untuk mencapai tujuan atau sasaran yang dimaksudkan (Tim Reality, 2008).

Adapun kata pendidikan sering dikaitkan dengan kata pengajaran yang dalam bahasa Arab disebut tarbiyah wa ta'lim. Sedangkan pendidikan Islam dalam bahasa Arab disebut Tarbiyah Islamiyah. Secara umum, pendidikan Islam adalah pembentukan kepribadian muslim (Sahlan, 2010). Pengertian pendidikan secara istilah sebagaimana dalam Undang- Undang RI Nomor 20 Tahun 2003 tentang Sistem Pendidikan Nasional, pasal 1 ayat (1), yaitu: Pendidikan adalah usaha sadar dan terencana untuk mewujudkan suasana belajar dan proses pembelajaran agar peserta didik secara aktif mengembangkan potensi diri untuk memiliki kekuatan spiritual keagamaan, pengendalian diri, kepribadian, kecerdasan, akhlak mulia, serta ketrampilan yang diperlukan dirinya, masyarakat, bangsa dan Negara (Redaksi Sinar Grafika, 2003). Adapun pengertian pendidikan Islam menurut beberapa ahli yaitu:

1) Pendidikan Islam ialah bimbingan yang diberikan oleh seseorang kepada seseorang agar ia berkembang secara maksimal sesuai dengan ajaran Islam. Bila disingkat, pendidikan Islam ialah bimbingan terhadap seseorang agar ia menjadi muslim semaksimal mungkin (Nata, 2016).

2) Pendidikan Islam adalah bimbingan terhadap pertumbuhan rohani dan jasmani menurut ajaran Islam dengan hikmah mengarahkan, mengajarkan, melatih, mengasuh dan mengawasi berlakunya semua ajaran Islam (Arifin, 2012).

3) Secara umum, pendidikan Islam adalah pembentukan kepribadian muslim (Nata, 2016).
Dari berbagai pendapat tentang pengertian pendidikan Islam, dapat disimpulkan bahwa pengertian pendidikan Islam adalah proses pembimbingan seseorang terhadap pertumbuhan rohani dan jasmani menurut ajaran Islam menuju kepribadian muslim. Dengan demikian yang dimaksud dengan manajemen pendidikan Islam adalah suatu proses penataan atau pengelolaan lembaga pendidikan Islam yang melibatkan sumber daya manusia muslim dan menggerakkannya untuk mencapai tujuan pendidikan Islam secara efektif dan efisien sebagaimana tergambar dalam pengertian di atas.

\subsection{Tata kelola pengembangan karakter moderat}

Menurut Marzuki \& Haq, karakter identik dengan akhlak sehingga karakter merupakan nilai-nilai perilaku manusia yang universal yang meliputi seluruh aktivitas manusia baik dalam rangka hubungan dengan Tuhan, diri sendiri, sesama manusia, maupun lingkungan yang terwujud dalam pikiran, sikap, perasaan, perkataan, dan perbuatanya berdasarkan norma-norma agama, hukum, tata karma, budaya dan adat (Marzuki \& Haq, 2018). Menurut Abdul Majid dan Dian Andayani karakter merupakan watak, sifat, atau hal-hal mendasar yang ada pada diri seseorang. Sering orang menyebutnya sebagai tabiat atau perangai. Karakter ini mempengeruhi segenap pikiran dan perbuatan manusia. Dari sudut pengertian, karakter dan akhlak keduanya tidak memiliki perbedaan yang signifikan. Keduanya didefinisikan sebagai suatu tindakan yang terjadi tanpa ada pemikiran lagi karena sudah tertanam dalam pikiran (Sudrajat \&Wibowo, 2013).

\section{METODE PENELITIAN}

Jenis penelitian ini merupakan penelitian kualitatif, metode penelitian yang berusaha menggambarkan dan menginterpretasikan objek sesuai dengan apa adanya. Sedangkan model pendeketan dalam penelitian ini adalah dengan pendekatan deskriptif yang menggunakan metode studi pustaka sebagai metodologi penyelesaiannya. Pengumpulan data penting dalam suatu penelitian, sebab data menjadi dasar dan alat untuk mencapai tujuan penelitian. Untuk memperoleh data yang diperlukan digunakan beberapa metode yang sekiranya sesuai dengan masalah yang diteliti. Dalam metode pengumpulan data ini, peneliti menggunakan metode kualitatif partisipatif (fieldwork relation). Di sinilah diperlukan kehadiran peneliti untuk tahu 
langsung kondisi dan fenomena di lapangan, tidak cukup meminta bantuan orang atau sebatas mendengar penuturan secara jarak jauh (Danim, 2002). Teknik pengumpulan data pada penelitian ini yaitu dengan observasi, wawancara dan dokumentasi. Metode yang digunakan untuk memeriksa keabsahan data adalah dengan triangulasi method yaitu dengan memanfaatkan berbagai metode sebagai pertimbangan. Triangulasi ini dilakukan dengan jalan membandingkan dan mengecek informasi atau data yang diperoleh dari dokumentasi dengan hasil pengamatan dan interview (Moleong, 2014). Triangulasi ini dilakukan dengan; (1) membandingkan data hasil pengamatan dengan data hasil wawancara, (2) membandingkan apa yang dikatakan orang di depan umum dengan yang dikatakan pribadi, (3) membandingkan apa yang dikatakan orang tentang situasi penelitian dengan apa yang didapat selama penelitian, (4) membandingkan keadaan dan perspektif seseorang dengan berbagai pendapat dan pandangan yang lain, dan (5) membandingkan hasil wawancara dengan isi suatu dokumen yang berkaitan.

\section{HASIL PENELITIAN}

\subsection{Penerapan Kurikulum Islam Moderat di Madrasah Aliyah Negeri 2 Surakarta}

Penerapan kurikulum di Madrasah Aliyah Negeri 2 Surakarta terkait Islam moderat diberikan dibeberapa mata pelajaran, kususnya mata pelajaran yang berkaitan dengan akidah dan akhlak agama ini seperti mata pelajaran PAI, Akidah Akhlak dan beberapa mata pelajaran lain. Konsep moderasi terutama moderasi agama sebenarnya dalam mata pelajaran yang ada di Madrasah Aliyah Negeri 2 Surakarta telah ada hampir dalam tiap materi khususnya materi-materi pada mata pelajaran keagamaan tadi. Pentingnya kurikulum pembelajaran tentang Islam moderat di madrasah disebabkan tidak sedikit dari siswa yang justru memahami makna Islam moderat tersebut secara terpisah sehingga yang awalnya memeiliki tujuan agar dapat menumbuhkembangkan pemahaman dan nilai-nilai Islam yang sangat universal dan baik, justru menyebarkan sikap egosentris keagamaan dengan selalu menganggap tidak benar orang lain yang berbeda pandangan serta pemahaman dengan dirinya jika tidak dipahamkan, salah satu pemahaman yang efektif yaitu melalui proses pembelajaran yang sebelumnya telah tersusun dalam kurikulum. Oleh sebab itu, kurikulum yang ada di Madrasah Aliyah Negeri 2 Surakarta yang berkaitan dengan pembelajaran Islam moderat disusun sedemikian rupa sehingga dalam penerapannya mampu memberikan pemahaman secara mendalam kepada setiap siswa di Madrasah Aliyah Negeri 2 Surakarta.

\subsection{Pelaksanaan Nilai Islam Moderat di Madrasah Melalui Budaya di Madrasah}

Sikap serta cara pandang moderat dalam beragama yang ada di lingkungan Madrasah Aliyah Negeri 2 Surakarta sudah menjadi ruhnya setiap siswa terlebih terhadap guru-gurunya. Setidaknya di Madrasah Aliyah Negeri 2 Surakarta terdapat beberapa bentuk integrasi terkait dengan pemahaman Islam moderat atau moderat dalam beragama yang selalu senantiasa di terapkan di lingkungan madrasah, antara lain melalui proses pembelajaran yang disampaikan setiap guru di dalam kelas, selanjutnya melalui proses pemahaman yang telah diwujudkan oleh Madrasah Aliyah Negeri 2 Surakarta melalui budaya di madrasah serta pemahaman yang telah diterapkan melalui berbagai kegiatan ekstrakurikuler yang diprogramkan. Pembangunan terhadap pemahaman Islam moderat di Madrasah Aliyah Negeri 2 Surakarta terus dilakukan pihak manajemen madrasah di bawah pimpinan kepala sekolah, hal itu dilakukan untuk menegaskan bahwasanya agama Islam merupakan agama yang cinta damai serta menjadi agama yang menjadi rahmat seluruh alam dan kehadirannya membawa kesejukan bagi siapapun meskipun berbeda agama. Islam senantiasa mencintai dan mengajarkan perdamaian serta menolak tindakan kekerasan maupun teror seperti yang dilakukan beberapa oknum yang tidak bertanggungjawab selama ini, sehingga seolah-olah Islam itu tidak menghargai perbedaan. Islam yang moderat dimana dalam menjalankan ajaran agama sesuai perintah Allah dan Rasulullah SAW yaitu mencintai sesama meskipun berbeda sekalipun dalam berbagai hal termasuk berbeda agamanya. Sebagaimanafirman Allah SWT dalam Al-Qur'an Surah Al-Kafirun ayat 6:

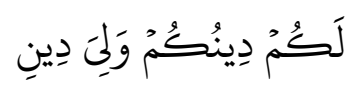

Artinya: "Untukmu agamamu dan untukkulah agamaku"

Moderasi dalam beragama terlebih dalam menciptakan karakter siswa agar menjadi Islam moderat tidak dapat dilepaskan dari berbagai nilainilai nasionalisme yang ada, penerapan tersebut juga dilakukan oleh pihak manajemen di Madrasah 


\section{Jurnal Ilmiah Ekonomi Islam, 7(01), 2021, 482}

Aliyah Negeri 2 Surakarta. Hal tersebut terus dilakukan pihak madrasah dalam rangka mengimbangi dan menangkal berbagai isu kekhalifahan yang ada di masyarakat saat ini yang cukup mengkhawatirkan bagi kelangsungan keragaman yang ada. Oleh sebab itu, kultur atau budaya yang ada di Madrasah Aliyah Negeri 2 Surakarta senantiasa mengutamakan jiwa-jiwa nasionalisme demi mewujudkan Islam yang moderat bagi para siswanya. Budaya yang dilakukan antara lain menyanyikan lagu Indonesia raya sebagai lagu wajib setiap upacara bendera yang dilaksanakan pihak madrasah. Selian menyayikan lagu Indonesia raya juga dalam setiap pelaksanaan kegiatan ekstrkurikuler sebagai wadah dalam mengintegrasikan dan menumbuhkembangkan nilainilai Islam moderat dan nasionalisme di lingkungan madrasah khususnya kepada siswa di Madrasah Aliyah Negeri 2 Surakarta untuk mewujudkan lulusan yang memiliki rasa kecintaan terhadap keberagaman yang ada.

\subsection{Pelaksanaan Nilai Islam Moderat di} Madrasah Melalui Kegiatan Ekstrakurikuler

Pelaksanaan nilai-nilai Islam yang moderat juga dilakukan di Madrasah Aliyah Negeri 2 Surakarta melalaui berbagai kegiatan ekstrakurikuler. Berbagai kegiatan ektrakurikuler yang dilaksanakan dalam rangka membantu dalam pembentukan karakter siswa di luar kelas agar mereka dapat bekerjasama dalam kegiatan tersebut sebagai wujud implementasi dan pelaksanaan kegiatan bersama-sama. Sehingga akan terbentuk sifat kebersamaan dan gotong royong serta saling menghargai setiap kemampuan, perbedaan yang ada diantara mereka. Hal tersebut tentunya menjadi fondasi dalam membentuk karakter setiap siswa di Madrasah Aliyah Negeri 2 Surakarta dalam mewujudkan generasi Islam yang moderat. Meskipun kegiatan ekstrakurikuler penting dalam membantu siswa membentuk karakter dan kepribadian, akan tetapi tetap tidak boleh mengganggu tugas utama mereka untuk senantiasa aktif dalam proses pembelajaran yang diselenggarakan oleh pihak madrasah di dalam.

Melalui kegiatan ekstrakurikuler yang dilakukan Madrasah Aliyah Negeri 2 Surakarta dapat membentuk jiwa dan sikap kepedulian siswa terhadap sesama, serta moderat dalam berbagai situasi dan kondisi baik ketika masih di lingkungan madrasah maupun saat berada di lingkungan masyarakat.

\section{KESIMPULAN}

Berdasarkan hasil penelitian dapat simbulkan bahwa manajemen pengembangan karakter muslim moderat pada siswa madrasah aliyah yang ada di Madrasah Aliyah Negeri 2 Surakarta dilakukan dengan beberapa hal yang dapat membuat karakter para siswa mampu memahami dan menghargai setiap perbedaan, yaitu 1) Penerapan kurikulum di Madrasah Aliyah Negeri 2 Surakarta terkait Islam moderat diberikan dibeberapa mata pelajaran, kususnya mata pelajaran yang berkaitan dengan akidah dan akhlak agama ini seperti mata pelajaran PAI, Akidah Akhlak dan beberapa mata pelajaran lain. 2) Madrasah Aliyah Negeri 2 Surakarta terdapat beberapa bentuk integrasi terkait dengan pemahaman Islam moderat atau moderat dalam beragama yang selalu senantiasa di terapkan di lingkungan madrasah, antara lain melalui proses pembelajaran yang disampaikan setiap guru di dalam kelas, selanjutnya melalui proses pemahaman yang telah diwujudkan oleh Madrasah Aliyah Negeri 2 Surakarta melalui budaya di madrasah serta pemahaman yang telah diterapkan melalui berbagai kegiatan ekstrakurikuler.

\section{REFERENSI}

Aeni, A. N. (2014). Pendidikan karakter untuk siswa sd dalam perspektif islam. Mimbar Sekolah Dasar, 1(1), 50-58.

Ananda, R., \& Amiruddin, A. (2019). Perencanaan Pembelajaran.

Arifin, Z. (2012). Pendidikan multikultural-religius untuk mewujudkan karakter peserta didik yang humanis-religius. Jurnal Pendidikan Islam, 1(1), 89-103.

Danim, S. (2002). Menjadi peneliti kualitatif.

Fattah, N., Hartati, T., \& Mulyasari, E. (2009). Manajemen Sekolah Bertaraf Internasional. Jurnal Educationist, 3(1).

Grafika, T. R. S. (2007). Undang-Undang Sistem Pendidikan Nasional Nomor 20 Tahun 2003. Jakarta: Sinar Grafika.

KBBI, T. (2008). Kamus Besar Bahasa Indonesia Pusat Bahasa. Penerbit PT Gramedia Pustaka Utama, Jakarta.

Kementrian Agama RI, (2019), Moderasi Beragama, Jakarta: Badan Litbang dan Diklat Kementrian Agama RI.

Maarif, M. A. (2018). Tasawuf Falsafi Dan Implikasinya Dalam Pendidikan Islam. Vicratina: Jurnal Pendidikan Islam, 3(1). 
Jurnal Ilmiah Ekonomi Islam, 7(01), 2021, 483

Marzuki, M., \& Haq, P. I. (2018). Penanaman nilainilai karakter religius dan karakter kebangsaan di Madrasah Tsanawiyah Al Falah Jatinangor Sumedang. Jurnal Pendidikan Karakter, 8(1).

Misrawi, Z. (2010). Pandangan Muslim Moderat: Toleransi, Terorisme, dan Oase Perdamaian. Penerbit Buku Kompas.

Moleong, L. (2014). J, Metodologi Penelitian Kualitatif, PT. Remaja Rosdakarya.

Nata, D. H. A. (2016). Ilmu pendidikan islam. Prenada Media.

Sahlan, A. (2010). Manajemen Pendidikan Islam. ArRuzz Media.

Simbolon, S. (2017). Pengaruh Kepemimpinan Visioner, Motivasi, dan Kompetensi terhadap Budaya Kerja dan Komitmen serta Implikasinya pada Kinerja Dosen. Kontigensi: Scientific Journal of Management, 5(2), 87-97.

Soemantri, A. S. (2011). Reading comprehension problems encounted by the students of higher education. Jurnal Computech \& Bisnis, 5(2), 7480 .
Sudrajat, A., \& Wibowo, A. (2013). Pembentukan Karakter Terpuji di Sekolah Dasar Muhammadiyah Condongcatur. Jurnal Pendidikan Karakter, 2(2).

Tilaar. (2004). Perkembangan Pendidikan Multikultural.

Terry, G. R. (1972). Principles of Management, Home Wood: Richard D. Irwin series in management, XIV, 703.

Usman, I. M. (2013). Pesantren sebagai lembaga pendidikan islam. Jurnal Al Hikmah, 14(1), 101119.

Wiyani, N. A. (2013). Pendidikan agama Islam berbasis anti terorisme di SMA. Jurnal Pendidikan Islam, 2(1), 65-83.

Zubaedy, M. (2012). Nilai-nilai Pendidikan Islam dalam Penyelenggaraan Tradisi Massempe'Masyarakat Desa Mattoanging Kecamatan Tellusiattinge Kabupaten Bone (Doctoral dissertation, Universitas Islam Negeri Alauddin Makassar). 